\title{
Molluscicidal Activity of Physalis angulata L. Extracts and Fractions on Biomphalaria tenagophila (d'Orbigny, 1835) under Laboratory Conditions
}

\author{
José Augusto A dos Santos/+ ${ }^{+}$, Therezinha Coelho B Tomassini, \\ Deise Cristina Drummond Xavier, Ivone Maria Ribeiro, Melissa Teixeira G da Silva, \\ Zenildo Buarque de Morais Filho*
}

\begin{abstract}
Núcleo de Biologia e Controle de Endo e Ectoparasita de Interesse Médico e Veterinário, Departamento de Biologia, Instituto Oswaldo Cruz-Fiocruz, Av. Brasil 4365, 21045-900 Rio de Janeiro, RJ, Brasil *Laboratório de Química de Produtos Naturais, Farmanguinhos-Fiocruz, Rio de Janeiro, RJ, Brasil
\end{abstract}

The main objective of this research is to evaluate the molluscicide activity of Physalis angulata $L$. Biomphalaria tenagophila specimens under laboratory conditions. Extracts and fractions were supplied by the Laboratório de Química de Produtos Naturais, Farmanguinhos-Fiocruz. Experiments were performed according to the methodology described by the World Health Organization for molluscicide tests using the concentrations from 0.1 to $500 \mathrm{mg} / \mathrm{l}$ of the extracts, fractions and of a pool of physalins modified steroids present in this species. The results show that ethyl acetate and acetone extracts from the whole plant, the ethanolic extracts of the roots and the physalins pool from stems and leaves were active. Only the whole plant extracts were available in sufficient quantity for the determination of $L D_{50}$ and $L D_{90}$ values.

Key words: molluscicidal activity - Physalis angulata L. - Solanaceae - Biomphalaria tenagophila

Schistosomiasis is a chronic and debilitating disease that affects people who have had contact with water harboring infected snails: rural workers, children, washerwomen from areas without a treated water supply and sewage system. The disease affects millions of people in several countries and is one of the world's main public health problems (OMS 1994).

The use of natural products in therapy through out the world is increasing, as well as the interest for research in this area.

Brazil, because of its wealth in biodiversity, has stimulated and focused research into new naturally derived drugs and this interest has extended to focus the field of vector control.

The search for more effective molluscicides, at lower costs and with less impact on the environment stimulated the search for potential active substances from native plants (Mott 1987). According to Baptista et al. (1994), 1,426 species of plants had been evaluated for molluscicide activity up to the time when he wrote his article. Notably active molluscicides are derived from specific parts of: Phytolacca dodecandra (Endod), Croton macrostachys, Jatropha curcas, Ambrosia maritima, Anarcardium occidentale (Kloos \& McCullough 1987, Kuo 1987, Jurberg et al. 1989, Souza et al. 1992).

${ }^{+}$Corresponding author. Fax: +55-21-2560.6474. E-mail: santosja@ioc.fiocruz.br

Received 29 July 2002

Accepted 26 February 2003
Euphorbia splendens var. hislopii shows high bio-active potential (Vasconcellos \& Schall 1986). Field work has been performed in order to evaluate the toxic effects (Schall et al. 1991) and molluscicide properties regarding temporal and seasonal evolution and geographical stability (Schall et al. 1992). From the latex of Euphorbia milii var. hislopii for example eight milliamines were isolated including five new substances (Zani et al. 1993).

Although several plants have been assayed in the search for molluscicidal activity, no reports have been published so far on Physalis angulata L.

The genus Physalis, which belongs to the family Solanaceae, includes about 120 species with herbal characteristics and perennial habits (Kissmann \& Groth 1995), distributed around the temperate and tropical zones of the world and some of them are used as food as well as in popular medicine. Physalins are steroidal constituents of Physalis sp. and are characterized by their modified ergostane-type framework, being 16,24-cyclo-13,14secosteroids (Vasina et al. 1986, Glotter 1991, Makino et al. 1995a, b, Tomassini et al. 2000).

$P$. angulata L. grows in the North and Northeast regions of the country where it is known as Camapu, Bucho de Rã, Joá or Juá de Capote and Mata-Fome (Branch \& Silva 1983). In Pará the fruit is eaten and the roots are used to treat hepatitis and malaria. Such uses are widespread due to the abundance of the plant and easy cultivation which contributes to a large scale use.

To date no phytopharmaceutical is known to control schistosomiasis and there is no reference in the literature concerning the molluscicidal activity of this plant. Considering the widespread use of Camapu throughout the country we decided to study the plant as a mean to control the snail vectors of schistosomiasis. 


\section{MATERIALS AND METHODS}

The Chemistry Laboratory of Natural Products, $\mathrm{PN}_{2}$ of Farmanguinhos, prepared the extracts, fractions and pool of physalins and the Department of Biology, Instituto Oswaldo Cruz-Fiocruz, performed the assays with snails.

Plant material - P. angulata was collected in October 1995 in Belém, State of Pará, Brazil. The identification and the classification was performed by Dr Lúcia d'A Freire Carvalho, from Jardim Botânico, Rio de Janeiro and an authentic sample stored at the herbarium of the Universidade Federal do Rio de Janeiro, Botany Departament under the reference number of RFA23907/8. Specimens were also cultivated in the Fundação Oswaldo Cruz's campus, Rio de Janeiro.

Snails studied - Specimens of Biomphalaria tenagophila from Jacarepaguá, Rio de Janeiro, RJ, were supplied by the Department of Malacology, Instituto Oswaldo Cruz-Fiocruz and kept in a 2771 culture tank filled with chlorine-free water, containing sterilized substratum consisting of red earth, calcium carbonate and oyster shell flour. The culture was mantained in the Department of Biology according to Paraense and Corrêa (1988), and the snails fed with fresh lettuce (Lactuca sativa L.).

Extracts and fractions of the plants employed - The whole plant and its parts, such as roots, stems, leaves, and fruits were dried at room temperature, ground and measured with ethanol, methanol, ethyl acetate, dichoromethane, chloroform, and hexane following a general procedure. Each extract was submitted to Mabry modified technique just to obtain the pool of physalins from which it is possible to get pure physalins such as withasteroid derivatives, that is seco-ergostanes having 28 carbon atoms, a ketone at $\mathrm{C}_{15}$, two lactones (furan and pyran type) attached at $\mathrm{C}_{18}$ and $\mathrm{C}_{20}$ positions respectively. A total of 11 extracts and 2 fractions of Physalis angulata $\mathrm{L}$. (Table I) were obtained and tested.

Preparation of the solutions to be tested - Each extract, fraction and pool of physalins was dissolved into $10 \mathrm{ml}$ of dimethyl sulphoxide (DMSO) and diluted to $1,000 \mathrm{ml}$ with distilled water. Solutions were obtained in the following concentrations: $0.1 \mathrm{mg} / 1,1 \mathrm{mg} / 1,10 \mathrm{mg} / 1,20$

TABLE I

Types of extracts and plant parts of Physalis angulata L. used in the experiments

\begin{tabular}{ll}
\hline Extract and fraction & Part used \\
\hline Ethanol & Leaf \\
Ethanol & Root \\
Ethanol & Whole plant \\
Ethanol & Stem \\
Ethyl acetate & Whole plant \\
Acetone & Whole plant \\
Dichloromethane & Whole plant \\
Aqueous & Stem \\
Aqueous & Capsule of the fruit \\
Methanol & Whole plant \\
Methanol & Fruit \\
Pool of physalins & Leaf \\
Pool of physalins & Stem \\
\hline
\end{tabular}

$\mathrm{mg} / 1,30 \mathrm{mg} / \mathrm{l}, 40 \mathrm{mg} / 1,50 \mathrm{mg} / 1,100 \mathrm{mg} / 1,150 \mathrm{mg} / 1,200 \mathrm{mg} /$ $1,250 \mathrm{mg} / \mathrm{l}, 300 \mathrm{mg} / \mathrm{l}, 400 \mathrm{mg} / \mathrm{l}$ and $500 \mathrm{mg} / \mathrm{l}$.

\section{Bio-assays}

Exposure period - Following the method described by WHO (1965), snails, with a shell diameter of 6-10 mm, were assayed side by side with a control (with distilled water) and an experimental group (with the solutions) for $24 \mathrm{~h}$.

Table II reports the different types of extracts, fractions, pool origins, and concentrations assayed as a first stage experimental technique. For each extract, fraction, pool, and control (distilled water) two beakers $1,000 \mathrm{ml}$ with 15 mollusks each were assayed in a total of 690 snails.

\section{TABLE II}

Mortality of Biomphalaria tenagophila, when submitted to different concentrations of extracts and fractions of Physalis angulata L. First trial

\begin{tabular}{lccc}
\hline Extract or fraction & $\begin{array}{c}\text { Concentration } \\
(\mathrm{mg} / \mathrm{l})\end{array}$ & $\begin{array}{c}\text { Dead } \\
\text { Cortality } \\
(\%)\end{array}$ \\
\hline Controle & 0 & 0 & 0 \\
Ethanol extract - leaves & 500 & 1 & 3.3 \\
Aqueous extract - stems & 500 & 2 & 6.7 \\
Acetone extract - whole plant & 500 & 22 & 73.2 \\
Ethanol extract - roots & 500 & 27 & 90 \\
Pool physalins - stems & 200 & 22 & 73.3 \\
Pool physalins - leaves & 200 & 28 & 93.3 \\
Ethyl acetate fraction - whole plant 100 & 22 & 73.3 \\
Pool physalins (leaves) & 100 & 27 & 90 \\
\hline
\end{tabular}

Number of snails: 30

Table III describes the second stage experimental run with the solutions that showed molluscicidal activity in the first test. The assay was made with 315 animals, at temperature of $26 \pm 1^{\circ} \mathrm{C}$. The snails were not fed during this period and all the groups were kept in $500 \mathrm{ml}$ of the respective solution.

Recovery period - At the end of each experiment, the snails were removed from the experimental solutions, rinsed in distilled water and kept in flasks of distilled water for $24 \mathrm{~h}$. The experimental temperature was maintained constant.

Identification of dead snails - After the recovery period, the identification of dead snails was made based on the snails' immobility and the odor of the soft parts.

Statistical analysis - Lethal doses $\left(\mathrm{LD}_{50}\right.$ and $\left.\mathrm{LD}_{90}\right)$, were evaluated by means of probit analysis (Finney 1971). The plot probit of kill against log of concentration (mg/l) provides a simple graphic representation of the doses response ratio.

\section{RESULTS}

The results of the first and second stage tests are summarized in Tables II and III, respectively. The other concentrations showed no significant mortality.

Table III shows the percentage of mortality during the lethal doses (LD) determination and Table IV the probit analysis data. 
TABLE III

Mortality of Biomphalaria tenagophila, when submitted to different extracts and fractions doses of Physalis angulata L. Second trial

\begin{tabular}{lccc}
\hline Extracts and fractions & $\begin{array}{c}\text { Concentration } \\
(\mathrm{mg} / \mathrm{l})\end{array}$ & Dead & $\begin{array}{c}\text { Mortality } \\
(\%)\end{array}$ \\
\hline CG & 0 & 0 & 0 \\
Ethyl acetate - whole plant & 20 & 1 & 6.7 \\
& 30 & 3 & 20 \\
& 40 & 5 & 33.3 \\
& 50 & 4 & 26.7 \\
Pool of physalins - leaves & 100 & 13 & 86.7 \\
& 150 & 13 & 86.7 \\
& 40 & 2 & 13.3 \\
Acetone extract - whole plant & 50 & 4 & 26.7 \\
& 100 & 10 & 66.7 \\
& 150 & 12 & 80 \\
Pool of physalins - stems & 200 & 9 & 60 \\
Ethanol extract - roots & 300 & 3 & 20 \\
\hline
\end{tabular}

CG: control group; number of snails: 15

\section{TABLE IV}

Lethal doses $\left(\mathrm{LD}_{50}\right.$ and $\left.\mathrm{LD}_{90}\right)$ for Biomphalaria tenagophila, obtained with solutions of the extracts and fractions of Physalis angulata $\mathrm{L}$.

\begin{tabular}{lrcc}
\hline Extracts and fractions & $\mathrm{N}$ & $\mathrm{LD}_{50}(\mathrm{mg} / \mathrm{l})$ & $\mathrm{LD}_{90}(\mathrm{mg} / \mathrm{l})$ \\
\hline Ethyl acetate - whole plant & 105 & 55.3 & 139.4 \\
Acetone extract - whole plant & 75 & 178.2 & 321.3 \\
Pool of physalins - leaves & 90 & 82.5 & 201.2 \\
\hline
\end{tabular}

$\mathrm{N}$ : number of snails

\section{DISCUSSION}

We agree with the analysis by Rouquayrol et al. (1980), who indicate that studies on the molluscicidal activity of plants, in planorbids, using different extracts (aqueous, alcohol and organic solvents) have provided partially promising results. However, we believe that the use against schistosomiasis should be postponed until further research in view of the existence of other trematodiosis of medical and veterinary importance.

According to Mott (1987) for a the plant to be considered as molluscicide, it should be registered in concentrations up to $100 \mathrm{mg} / \mathrm{l}$ and be able to kill $90 \%$ of the snails, $24 \mathrm{~h}$ after contact. On the other hand, Farnsworth et al. (1987) agreed to a maximum concentration tested of up to $100 \mathrm{mg} / \mathrm{l}$. However, they use percentage scales that allow the discrimination of the molluscicidal activity as weakly active and active, depending on the number of dead snails. Therefore, we decided to adopt of Farnsworth's et al. (1987) methodology. According to the records, the results obtained from several plant parts of $P$. angulata with solvents of different polarities showed that solutions prepared from some extracts (ethanolic from the leaves and roots, aqueous from the stem, acetone from the whole plant) were weakly active, at a concentration of $500 \mathrm{mg} / \mathrm{l}$; however the pool of physalins (stems) was weakly active at a concentration of $200 \mathrm{mg} / \mathrm{l}$, while in the ethyl acetate extract from the whole plant and the pool fraction of physalins from the leaves were considered active, at the concentration of $100 \mathrm{mg} / \mathrm{l}$. Ethanolic extracts from the stem, methanolic, dichloromethane and ethanolic from the whole plant, aqueous from the capsule of the fruit, and methanolic from the fruit were inactive in the first assay (Table II), contrary to Farnsworth's et al. (1987) report. However, the reported methodology is unclear and leaves many gaps. The present results, using the described methodology allow the determination of $\mathrm{LD}_{50}$ and $\mathrm{LD}_{90}$ in the solutions.

Rouquayrol et al. (1973), working with leaves, fruit, stem, root, and seeds of Pithecelobium multiflorum Bent (canafistula), using the crude aqueous and ethanolic raw extracts, measured the molluscicidal activity; these results were also observed with hexane extracts, as indicated by Mendes et al. (1984). However, we did not use the methodology of Rouquayrol et al. (1980), in which the solution in distilled water was neutralized by the addition of dilute aqueous hydrochloric acid or aqueous sodium hydroxide, although the authors registered positive results. In the assays with $P$. angulata, $\mathrm{pH}$ adjustment of the tested solutions was avoided, because, according to Fox et al. (1963) and Pereira and Souza (1974), any $\mathrm{pH}$ alteration in the solutions to be tested, is capable of influencing the result. Regarding the used parts of the plant, several authors worked with raw extracts (Mendes et al. 1984) and fractions (Pereira et al. 1978), a methodology which we followed and with which we obtained positive results also confirming the differences among parts used. Thus ethanolic extracts from the leaves and roots of $P$. angulata are molluscicidal, ethanolic extracts from the stem and the whole plant are inactive.

Analyzing these results, from the 13 different forms and extracts tested in the laboratory 5 (ethyl acetate and in acetone from the whole plant, ethanolic from the root, pool of physalins from the stem and the leaves) showed molluscicidal activity. For 3 of them (ethyl acetate and acetone extracts from the whole plant and pool of physalins from the leaves) $\mathrm{LD}_{50}$ and $\mathrm{LD}_{90}$ could be determined.

\section{REFERENCES}

Baptista DF, Vasconcellos MC, Lopes FE, Silva IP, Schall VT 1994. Perspectives of using Euphorbia splendens as a molluscicide in schistosomiasis control programs. Southeast Asian J Trop Med Public Health 3: 419-424.

Branch LC, Silva MFD 1983. Folk medicine of Alter Chão, Pará, Brasil. Acta Amazonica 13: 737.

Farnsworth NR, Henderson TO, Soejarto DD 1987. Plants with potential molluscicidal activity. In KE Mott, Plant Molluscicides. Chichester and Elsewhere, John Wiley \& Sons Ltd/ UNDP/World Bank/WHO, New York, p. 131-204.

Finney DJ 1971. Probit Analysis, 3rd ed., Cambridge Press, New Delhi, 333 pp. 
Fox L, Ritchie LS, Frick LP 1963. Effect of pH on Molluscicidal Activity of Bayer 73 Versus Australorbis glabratus of Puerto Rico under Laboratory Conditions, WHO, Geneva.

Glotter E 1991. Withanolides and related ergostane - type steroids. Nat Pro Rep 8: 415-440.

Jurberg PJ, Vasconcellos MC, Mendes N 1989. Plantas empregadas como moluscicidas: uma visão crítica. $\mathrm{Mem}$ Inst Oswaldo Cruz 84: 76-83.

Kissmann KG, Groth D 1995. Plantas Infestantes e Nocivas, Tomo III, BASFSA, p. 485-487.

Kloos H, McCullough FS 1987. Plants with recognized molluscicidal activity. In K E Mott, Plant Molluscicides, Chichester and Elsewhere, John Wiley \& Sons Ltd. UNDP/World Bank/ WHO, New York, p. 45-108.

Kuo YH 1987. Plant molluscicide studies in the people in Republic of China. In KE Mott, Plant Molluscicides. Chichester and elsewhere, John Wiley \& Sons Ltd. UNDP/ World Bank/WHO, New York, p. 220-298

Makino B, Kawai M, Ogura T, Nakanishi M, Yamamura H, Butsugan Y 1995a. Structural revision of Physalin H isolated from Physalis angulata L. J Nat Prod 58: 1668-1674.

Makino B, Kawai M, Yasushi I, Yamamura H, Butsugan Y, Ogawa K, Hayashi M, 1995b. Physalins prossessing an endoperoxy structure from Physalis alkekengi var. francheti: structural revision of Physalin K. Bull Chem Soc Jpn 68: 219-226.

Mendes NM, Pereira JP, Souza CP, Azevedo MLL 1984. Ensaios preliminares, em laboratório, para verificar a ação moluscicida de algumas espécies da flora brasileira. Rev Saúde Públ S. Paulo 18: 348-354.

Mott KE 1987. Plant Molluscicides, UNDP/World Bank/WHO, John Wiley \& Sons Ltd., New York, 326 pp.

OMS-Organização Mundial de Saúde 1994. O Controle da Esquistossomose: Segundo Relatório do Comitê de Especialistas da OMS, Fiocruz, Rio de Janeiro.

Paraense WL, Corrêa LR 1988. Self-fertilization in the freshwater snails Helisoma dury and Helisoma trivolvis. Mem Inst Oswaldo Cruz 83: 405-409.

Pereira JP, Souza CP 1974. Ensaios preliminares com
"Anacardium occidentale" como moluscicida. Ci e Cul 26: 1054-1057.

Pereira JP, Souza CP, Mendes NM 1978. Propriedades moluscicidas da Euphorbia cotinifolia L. Rev Bras Pesq Méd Biol 11: 345-351.

Rouquayrol MZ, Fonteles MC, Alencar JE, Matos FJA, Craveiro AA 1980. Atividade moluscicida de óleos essenciais de plantas do nordeste brasileiro. Rev Bras Pesq Méd Biol 13: 135-143.

Rouquayrol MZ, Souza MP, Matos FJA 1973. Atividade moluscicida de Pithecelobium multiflorum. Rev Soc Bras Med Trop 7: 11-19.

Schall VT, Vasconcellos MC, Valent GU, Sato MIZ, Furlan EV, Sanchez PS 1991. Evaluation of the geotoxic activity and acute toxicity of Euphorbia splendens, a molluscicide for the control of schistosomiasis. Braz J Med Biol Res 24: 573-582.

Schall VT, Vasconcellos MC, Villaça-Coelho AL, Ferreira-Lopes FE, Silva IP 1992. Evaluation of temporal, seasonal and geographic stability of the molluscicidal property of Euphorbia splendens Látex. Rev Inst Med Trop São Paulo 34: 183-191.

Souza CP, Mendes NM, Jannotti-Passos LK, Pereira JP 1992. O uso da casca da castanha de caju, Anacardium occidentale, como moluscicida alternativo. Rev Inst Med Trop São Paulo 34: 459-466.

Tomassini TCB, Barbi NS, Ribeiro IM, Xavier DCD 2000. Gênero Physalis - Uma revisão sobre vitaesteroides. Química Nova 23: 47-57.

Vasconcelos MC, Schall VT 1986. Latex of "Coroa de Cristo" (Euphorbia splendens): an effective molluscicide. Mem Inst Oswaldo Cruz 81: 475-476.

Vasina OE, Maslennikova VA, Abubakirov NK 1986. Physalis withasteroids. Khim Priord Soed 3: 243-255.

WHO-World Health Organization 1965. Molluscicide screening and evaluation. Bull WHO 33: 567-581.

Zani CL, Marston A, Hamgurger M, Hostettmann K 1993. Molluscicidal milliamines from Euphorbia milii var. Hislopii. Phytochemistry 34: 89-95. 